\title{
Kompetencje pedagogiczne nauczycieli wczesnej edukacji - relacja z badań własnych
}

\author{
Lata szkolne sa górami, \\ z których rzeka życia bierze swój poczqutek, \\ rozpęd i kierunek. Któż śmie je lekceważyć?
}

Janusz Korczak $^{1}$

Słowa wielkiego przyjaciela dzieci Janusza Korczaka trafiają w samo sedno istoty zawodu nauczyciela pierwszego szczebla kształcenia. Zawodu szczególnego, nie dającego się porównać z żadnym innym. Co stanowi o tym, że praca nauczyciela na tym etapie edukacji jest tak wyjątkowa?

Nie od dziś wiadomo, że nauczyciel kształcenia zintegrowanego odgrywa specyficzną i niepowtarzalną rolę na drodze życia ucznia jako najwyższy autorytet i wzór do naśladowania. Od niego zależy postawa dziecka wobec szkoły jako instytucji edukacyjnej, wobec nauczycieli i obowiązków szkolnych. Cechy osobowe nauczyciela oraz jego kompetencje pedagogiczne do wykonywania zawodu są bardzo ważne, ponieważ od nich w dużym stopniu zależy rozwój dziecka w zakresie wszystkich sfer osobowości, a więc nie tylko w zakresie „dyspozycji” intelektualnych, ale także postaw społecznych, przyswojonych wartości moralnych, kultury, zdrowia i rozwoju fizycznego. Nauczyciel klas I-III, podejmując zadanie kształtowania osobowości na szczeblu propedeutycznym, kładzie podwaliny dla kolejnych etapów kształcenia. Współczesny nauczyciel nauczania początkowego traktuje proces nauczania - uczenia jako proces badawczy, w którym uczeń samodzielnie dochodzi do rozwiązania określonych problemów, wykazuje aktywną i twórczą postawę wobec świata. Takiego ucznia może przygotować tylko twórczy nauczyciel. Taki, który promuje w pracy nowatorskie pomysły, jest otwarty na pomysły innych, stale wzbogacający swą wiedzę merytoryczną i podnoszący swoje kompetencje zawodowe. Praca nauczyciela twórczego charakteryzuje się nieustannym

\footnotetext{
${ }^{1}$ Artykuły medyczne Janusza Korczaka z okresu międzywojennego. Słowo wstępne [Do rozprawy Jędrzeja Śniadeckiego o fizycznym wychowaniu młodzieży, 1920].
} 
poszukiwaniem, badaniem, eksperymentowaniem, zaangażowaniem w realizację celów procesu edukacyjnego. Nauczyciel kreatywny musi akceptować samego siebie, aby akceptować swoich wychowanków, rozumieć ich i potrafić im pomóc. Twórcze działanie nauczycieli daje gwarancje wysokiego poziomu kształcenia. B. Kwiatkowska-Kowal wskazuje nawet na „wielofunkcyjność” zawodu nauczyciela, który powinien być jednocześnie źródłem wiedzy, przewodnikiem, ale też przyjacielem dziecka, potrafiącym zrozumieć jego problemy i chwilowe niedyspozycje ${ }^{2}$.

W obliczu rozwoju społeczeństwa informacyjnego, procesów globalizacji gospodarki i kultury, wdrażanej obecnie reformy edukacji oraz samej natury profesji nauczycielskiej, w której wiedza i umiejętności zdobyte w trakcie przygotowania do zawodu szybko okazują się niewystarczające, zasadnym wydaje się podjęcie problemu diagnozy zasobu kompetencji pedagogicznych nauczycieli wczesnej edukacji.

Co oznacza termin „kompetencja”? W. Okoń pisze, że w pedagogice kompetencja (z łac. competentia) stanowi podstawowy warunek wychowania i określa ją jako - „odpowiedzialność, zgodność, uprawnienie do działania ${ }^{3}$. B. Żechowska natomiast przyjmuje definicję bardziej ogólną, zakładającą wielość kompetencji. Dzieli je na dwie grupy. Pierwsza grupa kompetencji koncentruje się na wyuczonych postawach lub naturalnych zdolnościach [...] radzenia sobie z problemami zyciowymi poprzez wykorzystywanie sprawności poznawczych $i$ społecznych. Druga zaś grupa akcentuje emocjonalne oraz motywacyjne znaczenie ocen i oczekiwań człowieka co do jego zdolności adaptacyjnych [...]. Wspólnym elementem, który da się wyróżnić w obu grupach definicji jest jakaś potencjalna zdolność do czegoś, swoista osobista możliwość wykorzystania tej zdolności ${ }^{4}$. M. Czerepaniak-Walczak uznaje, że istotne treści dla rozumienia tego pojęcia zawierają definicje autorów zagranicznych. Według O. H. Jenkinsa kompetencja to zdolność i gotowość do wykonywania zadań na określonym poziomie ${ }^{5}$, a zdaniem M. Erauta zdolność do wypetniania wymaganych zadań $i$ ról przy spetnianiu oczekiwanych standar$d o w^{6}$. Podobne znaczenie tego terminu przekazuje D. Fontana pisząc, że stanowi ona sprawność niezbędną do radzenia sobie $\mathrm{z}$ problemami, jest wyuczalną

${ }^{2}$ B. Kwiatkowska-Kowal, Ksztatcenie nauczycieli w szkole wyższej, Warszawa 1994, s. 222.

${ }^{3}$ W. Okoń (red.), Nowy Stownik Pedagogiczny, Warszawa 2004, s. 185.

${ }^{4}$ B. Żechowska, O twórczym rozwoju nauczyciela refleksji kilka, [w:] Twórczy rozwój nauczyciela, pod red. S. Juszczyk, Kraków 1996, s. 57.

${ }^{5}$ M. Czerepaniak-Walczak, Aspekty i źródta profesjonalnej refleksji nauczyciela, ToruńPoznań 1997, s. 87.

${ }^{6}$ M. Eraut, Developing Professional knowledge and competence, [w:] Professional Development in Education: New Paradigms and Practices, pod red. T. R. Guskey, M. Huberman, Columbia University: Teachers College Press 1995, s. 236-237. 
umiejętnością robienia rzeczy dobrze ${ }^{7}$. W konsekwencji M. Czerepaniak-Walczak uznaje, że kompetencja to szczególna właściwość wyrażająca się $w$ demonstrowaniu na wyznaczonym przez spoteczne standardy poziomie, umiejętności adekwatnego zachowania się, $w$ świadomości potrzeby i konsekwencji takiego wtaśnie zachowania oraz $w$ przyjmowaniu na siebie odpowiedzialności za nie, a ujmując syntetycznie harmonijna kompozycja wiedzy, sprawności, rozumienia oraz pragnienia ${ }^{8}$.

Powyższe definicje dowodzą, że specyficzna cecha kompetencji wyraża się w tym, iż jest ona zawsze właściwością określonej osoby-- jest więc kategorią podmiotową związaną z formą aktywności człowieka, której sednem jest „umiejętność”. Jednak nie można jej utożsamiać tylko ze sprawnością, gdyż byłoby to ograniczeniem jej istoty. Zwróciła na to uwagę B. Gołębniak, która wzbogaciła zakres kompetencji jako refleksyjnego, szeroko uzasadnionego i „przepełnionego wiedzą" działania, komponentami w postaci zdolności, umiejętności, sprawności, wiedzy przedmiotowej, postaw i gotowości do współpracy z innymi profesjonalistami. Ponadto, według w/w autorki, „,kompetencja jest integracją myślenia i krytycznej refleksji, która determinuje odpowiednie ustosunkowanie się do kontekstu działaniowego, świadomość moralną i profesjonalny osąd". Podmiotowy wymiar kompetencji wiąże się również, co w przypadku nauczyciela jest szczególnie ważne, z racjonalną i krytyczną oceną własnego postępowania, poczuciem sprawstwa, transgresji i rozwoju, odkrywaniem możliwości całościowego sukcesu w wymiarze indywidualnym i zbiorowym ${ }^{9}$. H. Kwiatkowska podkreśla, że kompetencja bywa uważana za rezultat procesu kształcenia i powstaje $w$ wyniku zintegrowania wiedzy, dużej liczby drobnych umiejętności oraz sprawności $w$ dokonywaniu wartościowañ ${ }^{10}$.

Należy jednak mieć świadomość, że osiagnięcie optymalnego zbioru kompetencji zawodowych pozostaje $\mathrm{w}$ sprzeczności $\mathrm{z}$ istotą pracy nauczyciela bowiem zawód nauczycielski należy do tych profesji, $w$ których nie da sie określić finalnej postaci kwalifikacji ${ }^{11}$. Wiedza, umiejętności i postawy decydujące o profesjonalnym i efektywnym nauczaniu, są zawsze niegotowe, niewystarczające, stale wymagają korekt, a więc muszą być nieustannie doskonalone i rozwijane. Jest to związane m.in. z szybko zmieniającymi się warunkami pracy i zmianami otoczenia społecznego, rozwojem wiedzy naukowej, niepowtarzalnością sytuacji edukacyjnych, czy komunikacyjnym charakterem pracy pedagoga. Nauczyciel działa w dynamicznej rzeczywistości - to znaczy otwartej na

${ }^{7}$ D. Fontana, Psychologia dla nauczycieli, Poznań 1998, s. 45.

${ }^{8}$ M. Czerepaniak-Walczak, Aspekty i źródta profesjonalnej refleksji nauczyciela, ToruńPoznań 1997, s. 87-88.

${ }^{9}$ B. Gołębniak, Zmiany edukacji nauczycieli: wiedza - biegłość - refleksyjność, ToruńPoznań 1998, s. 145.

${ }^{10}$ H. Kwiatkowska, Pedeutologia, Warszawa 2008, s. 35.

${ }^{11}$ Tamże, s. 205. 
zmienność, niestereotypowość, różnorodność i konflikty. Spotyka się z uczniami, rodzicami, nauczycielami, z których każdy jest inny. Nie może więc przewidzieć ani problemów, ani zadań przed jakimi zostanie postawiony. Spotkania te wymagają nieustannego dialogu pomiędzy partnerami edukacyjnymi, a także uzgodnienia wspólnej interpretacji świata i wartości, które nadają życiu sens.

Sprecyzowane kompetencje charakteryzują kwalifikacje ludzi w poszczególnych zawodach, a także są swoistą gwarancją osiagania przez nich sukcesów zawodowych. Tylko ludzie o określonych i wysokich kompetencjach mogą być mistrzami w swojej profesji. Jakimi zatem kompetencjami powinien dysponować współczesny nauczyciel edukacji początkowej?

M. i R. Radwiłowiczowie, poszukiwacze odpowiedzi na pytanie, co powinno cechować pracę nauczyciela małego ucznia i jakim człowiekiem ma być on sam uznali, że nauczyciel edukacji początkowej jest pierwszym nauczycielem, który wprowadza dziecko $w$ sposób systematyczny w szeroko rozumiany świat wspótczesny. Jeśli zatem $w$ tym pierwszym okresie nauki popetni się wobec dziecka nawet pozornie mało znaczace błędy, mogq one zaważyć na całej jego karierze szkolnej ${ }^{12}$. Na kolejnych etapach kształcenia uczniowie będą poszerzać I konsekwentnie rozwijać dzięki niemu zdobyte umiejętności, z czasem niezbędne do planowania własnego rozwoju i podejmowania coraz ważniejszych decyzji życiowych.

Według J. Jaśkowskiej proces nauczania na tym etapie wiąże się z pobudzaniem, aktywizowaniem, rozwijaniem twórczych postaw 7-10-letnich wychowanków, skłanianiem do podejmowania różnych działań kreatywnych, wspieraniem w dążeniu do celu. Nabywanie kompetencji odbywa się poprzez aktywne działanie oraz uczenie się wszystkimi zmysłami. Tak pojmowana idea zintegrowanej edukacji wymaga określonego sposobu nauczania, w którym łączą się i uzupełniają cele i treści z różnych dziedzin, formy organizacyjne oraz formy aktywności dzieci i nauczyciela w ramach wspólnych jednostek tematycznych: nie może być mowy o dalszych etapach nauczania $i$ wychowania, jeżeli już $w$ nauczaniu zintegrowanym nie stworzymy wtaściwych warunków do samodzielnej, twórczej pracy, harmonijnego wspótżycia $w$ zespole $i$ samodzielnego pokonywania trudności $w$ każdej nowo powstatej sytuacji, gdy nie nauczymy dziecka, jak ma się uczyć. To, czy ten życiowy start będzie udany, $w$ dużej mierze zależy od nauczyciela ${ }^{13}$. $\mathrm{Z}$ powyższych względów nauczaniem zintegrowanym powinny zajmować się osoby posiadające specyficzne kompetencje.

Refleksji nad kompetencjami nauczycieli edukacji początkowej wobec nowych zadań i sytuacji wynikających z reformy systemu szkolnego dokonuje Z. Ratajek. Autor podkreśla, iż muszą oni dysponować swoistymi kwalifikacja-

\footnotetext{
${ }^{12}$ M. Radwiłowicz, R. Radwiłowicz, Nauczyciel klas poczatkowych, Warszawa 1981.

${ }^{13}$ J. Jaśkowska, Kompetencje nauczycieli, ,Życie szkoły” 2003, nr 8, s. 472.
} 
mi profesjonalnymi, których struktura zwiqzana jest $z$ [...] nowymi powinnościami polegajacymi na wprowadzaniu dziecka $w$ całościowo pojmowany świat zjawisk przyrodniczo - społecznych, pomaganiu dziecku bycia $w$ nim z cata wrażliwościa podmiotowa, stopniowym stawaniu się świadomym jego odbiorca i twórcq ${ }^{14}$. Charakterystycznym elementem koncepcji w/w autora jest wyróżnienie i nacisk na sztukę wykonywania zawodu nauczyciela klas I-III w obliczu nowych rozwiązań edukacyjnych, strukturalnych, programowych i metodycznych. Uważa on za oczywiste, że w strukturze kwalifikacji nauczyciela powinny znaleźć się dwa podstawowe obszary wiedzy i kompetencji. Pierwszy związany z podmiotowymi wartościami osób uczestniczących w procesie kształcenia oraz sposobami i warunkami ich wzajemnego edukacyjnego kontaktu zwany kompetencjami psychologiczno-pedagogicznymi. Drugi obszar związany z treściami kształcenia: językowymi, matematycznymi, przyrodniczymi, społecznymi, estetycznymi i technicznymi określany jako kompetencje merytoryczne ${ }^{15}$.

H. Hamer uważa, że nauczyciel wczesnej edukacji powinien posiadać trzy rodzaje kompetencji, a mianowicie: kompetencje specjalistyczne, czyli wiedzę i umiejętności dotyczące nauczania elementarnego, gdzie działalność edukacyjna obejmuje różne dziedziny - edukacja polonistyczna, matematyczna, środowiskowa, plastyczna, muzyczna, techniczna, ruchowa; kompetencje dydaktyczne, w których skład wchodzi m.in. umiejętność projektowania zintegrowanych jednostek tematycznych, uwzględnianie specyfiki rozwojowej dzieci w młodszym wieku szkolnym, opanowanie sztuki motywowania uczniów do nauki, umiejętność diagnozowania dziecka i jego rozwoju; kompetencje psychologiczne, np. umiejętność porozumiewania się ze wszystkimi podmiotami edukacyjnymi, budowania zgranego zespołu uczniowskiego i kierowania nim, umiejętność kontrolowania emocji ${ }^{16}$. Podział kompetencji nauczycieli nauczania początkowego podany przez $\mathrm{H}$. Hamer opiera się na idei integracji w zreformowanej szkole. Autorka słusznie podkreśliła, np. umiejętność właściwego projektowania jednostek tematycznych zgodnie $\mathrm{z}$ zasadami organizacji procesu edukacyjnego nauczania zintegrowanego.

Niezwykle interesujący model kompetencji niezbędnych współczesnemu nauczycielowi wyeksponowała J. Szempruch ${ }^{17}$. Obejmuje on kompetencje interpretacyjno-komunikacyjne, kreatywności, współdziałania, pragmatyczne i informatyczno-medialne.

${ }^{14}$ Z. Ratajek, Nauczyciele edukacji poczatkowej wobec nowych zadań $i$ sytuacji wynikajacych z reformy systemu szkolnego, [w:] Edukacja wczesnoszkolna u progu reformy, pod red. Z. Ratajek, t. 3, Kielce 2000, s. 73.

${ }^{15}$ Tamże, s. 74.

${ }^{16}$ H. Hamer, Klucz do efektywności nauczania - poradnik dla nauczycieli, Warszawa 1994.

${ }^{17}$ J. Szempruch, Nauczyciel w zmieniajacej się szkole - funkcjonowanie i rozwój zawodowy, Rzeszów 2001. 
Kompetencje interpretacyjno-komunikacyjne są zasadniczym elementem składowym kwalifikacji nauczycielskich. H. Kwiatkowska pisze, że czymś absolutnie podstawowym jest umiejętność dialogu z drugim człowiekiem i z samym sobq ${ }^{18}$. Prymat kompetencji interpretacyjno-komunikacyjnych jest uzasadniony swoistością tego zawodu - dzięki nim dopiero mogą być użyte kompetencje dotyczące projektowania (obmyślania programu) i organizowania przekazu (doboru metod, form, środków) informacji przedmiotowych czyli wąsko pojętego nauczania. Aby formułować wszelkie cele, sięgać po metody i środki, nauczyciel winien odpowiedzieć sobie na pytanie, co powinien zrobić by nie stały się one w jego rękach narzędziem manipulacji i zniewalania ucznia i w jaki sposób posłużyć się nimi w konkretnej sytuacji edukacyjnej. Kompetencje interpretacyjno-komunikacyjne wyrażają się umiejętnością rozumienia i definiowania sytuacji edukacyjnych oraz skutecznością zachowań komunikacyjnych, zarówno werbalnych, jak też niewerbalnych. Z. Nęcki podkreśla, że na akt bezpośredniej komunikacji składaja się, poza warstwa językowa, także gesty, mimika, intonacja, tempo mówienia, akcentacja, pozycja ciała, odległość fizyczna, wymiana spojrzeń czy nawet przemieszczanie przedmiotów ${ }^{19}$. Oprócz tego kompetencje interpretacyjno-komunikacyjne dotyczą umiejętności nawiązywania i podtrzymywania kontaktu z uczniem, właściwego odbierania i interpretowania przekazów edukacyjnych, a także rozumienia dialogowego charakteru relacji nauczyciel - uczeń. Istotne znaczenie ma zdolność do komunikowania się na poziomie empatii.

Głównym zadaniem nauczyciela, oprócz przekazu wiadomości, jest tworzenie sytuacji problemowych i stymulowanie twórczych postaw edukacyjnych uczniów. W pracy nauczyciela zasadniczą rolę pełnią więc kompetencje kreatywności manifestujące się niekonwencjonalnością jego działań, zdolnościq do reinterpretacji, wedtug najnowszych osiagnięć nauki, wszystkiego, co pedagogicznej dziatalności podlegać powinno ${ }^{20}$, rozumieniem i umiejętnością działania na rzecz zwiększenia autonomii podmiotów edukacyjnych. Kompetencje kreatywności przejawiają się w zachowaniu nauczyciela, który tworzy i przekształca elementy własnego warsztatu pracy (np. opracowuje autorskie programy nauczania), znając przy tym możliwości i bezpieczne granice w dokonywaniu twórczych zmian i dokonuje nad nimi refleksji.

Ważną rolę $\mathrm{w}$ aktywności zawodowej nauczyciela pełnią kompetencje współdziałania, które wchodzą w skład standardów kompetencji zawodowych nauczyciela. Są one widoczne w prospołecznych zachowaniach nauczyciela

${ }^{18}$ H. Kwiatkowska, Edukacja nauczycieli. Konteksty - kategorie - praktyki, Warszawa 1997, s. 89.

${ }^{19}$ Z. Nęcki, Komunikacja międzyludzka, Kluczbork 2000, s. 45.

${ }^{20}$ J. Niemiec, Nauczyciel w przemianie i perspektywie, [w:] Rozwój nauczyciela w okresie transformacji, pod red. W. Prokopiuk, Białystok 1998, s. 32. 
i umiejętnym integrowaniu zespołów uczniowskich. Nauczyciel, który dysponuje kompetencjami współdziałania, jest wyposażony w wiedzę o prawidłowościach współdziałania i rozwoju społecznym uczniów, sprawności w modyfikowaniu własnego stylu kierowania grupą wychowanków w zależności od stopnia ich rozwoju i dojrzałości społeczno - moralnej oraz rozumienie potrzeby współpracy z pozaszkolnymi uczestnikami procesu edukacyjnego i umiejętności współdziałania na rzecz tworzenia warunków do uczenia się we współpracy i współodpowiedzialności za końcowy ich efekt.

Przedmiotem wszechstronnych analiz stają się również kompetencje pragmatyczne. Według J. Rusieckiego kształcenie pragmatyczne formułuje umiejętności wychowawcze, opiekuńcze, diagnostyczne i terapeutyczne przyszłych nauczycieli ${ }^{21}$. Kompetencje pragmatyczne posiada nauczyciel, który dysponuje podstawową wiedzą psychologiczną, pedagogiczną i metodyczną, umiejętnie różnicuje projekty działania w zależności od dokonanych diagnoz, od podmiotowych możliwości ucznia oraz materialnych i kulturowych warunków działania, a także realizuje założenia edukacji integracyjnej. Nieobce jest mu prawodawstwo zawodowe oraz prowadzenie dokumentacji wymaganej przez szkołę. Szczyci się umiejętnością planowania własnej koncepcji doskonalenia I samokształcenia zawodowego.

Kompetencje informatyczno-medialne wyrażają się umiejętnością wykorzystania technologii informacyjnej i komunikacyjnej w doskonaleniu procesów edukacyjnych. W ich zakresie wskazuje się, m.in. na zdolność obsługi komputera, wideo i innego sprzętu technicznego, wykorzystywanie technologii informatycznej $\mathrm{w}$ pracy $\mathrm{z}$ dziećmi (Internet, poczta elektroniczna), publikowanie własnych prac edukacyjnych (scenariusze, artykuły) na stronach $\mathrm{WWW}^{22}$. Ciekawe spojrzenie na kwalifikacje informatyczne przedstawia również W. Osmańska-Furmanek. Według tej autorki najbardziej istotnym dla nauczyciela i pedagoga rodzajem kompetencji informatycznych są kompetencje z zakresu zastosowania technologii informacyjnej w jego działalności zawodowej. Wśród nich wymienia się: umiejętności projektowania procesu dydaktycznego z zastosowaniem multimediów (przede wszystkim komputera, jako najbardziej uniwersalnego narzędzia multimedialnego), metodyki wykorzystania technologii informacyjnej w procesie edukacji, zasad projektowania, realizacji i wykorzystania prezentacji multimedialnych, zasad projektowania, realizacji i wykorzystania programów edukacyjnych, interaktywno-multimedialnych z obiektowo-wizualnymi językami programowania wyższego rzędu, reguł tworzenia, percepcji i oddziaływania komunikatu multimedialnego, nowych form komunikacji poprzez elektroniczne media edukacyjne, zapoznanie się z możliwościami

\footnotetext{
${ }^{21}$ J Rusiecki, Nauczyciel okresu transformacji - próba diagnozy zawodu, Olsztyn 1999.

${ }^{22}$ J. Szempruch, Nauczyciel w zmieniajacej się szkole - funkcjonowanie i rozwój zawodowy, Rzeszów 2001, s. 114-119.
} 
edukacyjnego zastosowania sieci Internet ${ }^{23}$. S. M. Kwiatkowski w zbiorze kompetencji informatycznych wyróżnia trzy podzbiory: pierwszy z nich obejmuje umiejętności obsługi sprzętu komputerowego oraz pracy z gotowymi programami, drugi podzbiór zawiera rozumienie podstawowych pojęć informatycznych, umiejętność zastosowania komputerów w procesie rozwiązywania zadań oraz wiedzę na temat społecznych uwarunkowań informatyzacji, a w trzecim podzbiorze znajduje się miejsce dla umiejętności programowania, w tym także tworzenia lub modyfikowania komputerowych programów dydaktycznych ${ }^{24}$. J. Górnikiewicz nazywa kompetencje informatyczne tymi, „których używanie przyczyni nauczycielom przyjemności" oraz wyraża przekonanie, że warto je posiadać i posługiwać się nimi ze względu na korzyści odnoszone w szkole i na co dzieńn ${ }^{25}$. B. Kędzierska traktuje informacyjno-komunikacyjne kompetencje nauczycieli jako integralną część kanonu kształcenia ogólnego oraz warunek dostosowania szkolnego procesu dydaktycznego do współczesnych uwarunkowań społeczno-technologicznych ${ }^{26}$.

Pomimo że kompetencje nie mają postaci finalnej, czyli są strukturą otwartą, którą można wzbogacać o nowe składniki, to jednak ten schemat wydał mi się możliwie optymalny dla celów mojej pracy badawczej.

W zagranicznej literaturze pedagogicznej również można znaleźć opracowania wybitnych pedagogów dotyczące problematyki kompetencji współczesnego nauczyciela. Dzięki nim można porównać standardy wykształcenia zawodowego polskich nauczycieli z nauczycielami w innych krajach, a także wzbogacić literaturę rodzimą o spostrzeżenia i doświadczenia zagranicznych specjalistów w zakresie pedeutologii.

Kompetencje nauczyciela - to istotny problem w pedagogice amerykańskiej, łączący się bezpośrednio z efektywnością. Mówi się często: nauczyciel efektywny - to nauczyciel kompetentny ${ }^{27}$.

I tak na przykład E. Perrot ciekawie nazwała prawidłowe wykonywanie zawodu przez nauczycieli jako „efektywne nauczanie”. Jako wyznaczniki skutecznego nauczania przytacza dziedziny nauczycielskiej kompetencji wyodrębnione przez B. O. Smitha. Są to: ,znajomość wiedzy teoretycznej na temat ludzkiego uczenia się i zachowania, kształtowanie postaw ułatwiających uczenie się i sprzyjające tworzeniu właściwych stosunków międzyludzkich, wiedza przed-

${ }^{23}$ W. Osmańska-Furmanek, Nowe technologie informacyjne w edukacji, Zielona Góra 1999.

${ }^{24}$ S. M. Kwiatkowski, Komputery $w$ procesie ksztatcenia i zarzadzania szkota, Warszawa 1994, s. 58.

${ }^{25}$ J. Górnikiewicz, Po tej samej stronie. Nauczyciele $i$ uczniowie $w$ Internecie $i$ multimedialnych widowiskach, [w:] Myśl pedeutologiczna i działanie nauczyciela, pod red. A. A. Kotusiewicz, Białystok 2000.

${ }^{26}$ B. Kędzierska, Kompetencje informacyjne $w$ ksztatceniu ustawicznym, Warszawa 2000.

${ }^{27}$ B. Żechowska, Efektywność pracy nauczyciela: wyznaczniki, tendencje, problemy, Katowice 1982 , s. 75 . 
miotowa dotycząca dziedziny, jaka ma być nauczana, opanowanie technicznych umiejętności nauczania, ułatwiających uczniowskie uczenie się ${ }^{28}$.

Wielki rozmach i powage mają prace nad standardami profesjonalnego poziomu i rozwoju nauczycieli w Stanach Zjednoczonych Ameryki Północnej (USA).

Amerykański pedagog R. I. Arends w swoim akademickim podręczniku dydaktyki, tłumaczonym na język polski, nie zastanawia się nad rangą poszczególnych grup kompetencji ,nie rozstrzyga też, czy kompetencje przedmiotowe są ważniejsze od wychowawczych, lub odwrotnie". Próbuje określić na czym polega skuteczne nauczanie oraz wymienia cztery cechy efektywnego nauczyciela, które stanowią jednocześnie cztery grupy kwalifikacji pedagogicznych. Po pierwsze taki nauczyciel włada zasobem wiedzy, na którym opiera się sztuka nauczania, po drugie dysponuje repertuarem najlepszych sposobów postępowania pedagogicznego, po trzecie wykazuje postawy i umiejętności niezbędne dla systematycznej refleksji i rozwiązywania problemów i po czwarte rozumie naukę nauczania jako proces ustawiczny ${ }^{29}$.

Traktowanie nauki nauczania jako procesu ustawicznego to istotny komponent, który również powinniśmy wnieść do naszych, polskich zbiorów kompetencji nauczycielskich. Nauczyciel powinien być nieustannie uczącym się podmiotem. Cywilizacja XXI wieku wymaga od niego edukacji permanentnej, stosowania w procesie dydaktyczno-wychowawczym nowoczesnych technologii, dostosowania się do podlegającej zmianom struktury szkoły, a także kreowania własnych pomysłów na skuteczne nauczanie.

$\mathrm{Na}$ istotę znajomości wiedzy przedmiotowej przez nauczycieli, ale także umiejętność jej przekazywania wskazują poglądy L. Cohena, L. Maniona, K. Morrisona. Kierowanie klasą, ocenianie i rejestrowanie postępów poszczególnych uczniów oraz dalsze samodoskonalenie zawodowe to pozostałe obszary kompetencji, które według nich powinny być kształtowane u przyszłych nauczycieli $^{30}$.

Z rozważań tych można wysnuć zasadniczy wniosek, iż kompetencje nauczyciela, czyli wiedza, umiejętności i przekonania są „siłą" konieczną, napędzającą jego pracę dydaktyczną, wychowawczą i opiekuńczą. Nauczyciel kompetentny to osoba wykształcona ogólnopedagogicznie, zdolna do nauczania interdyscyplinarnego, dostrzegająca ważne tematy współczesnego świata, co w konsekwencji wpływa na rozwój mistrzostwa pedagogicznego.

Potrzeba debaty o kondycję polskiego nauczyciela edukacji wczesnoszkolnej w reformowanej szkole XXI wieku stała się motywatorem do przeprowadzenia badań pedeutologicznych rozpoznających i poddających refleksji sytuację nauczyciela realizującego kształcenie zintegrowane w środowisku szkolnym.

\footnotetext{
${ }^{28}$ E. Perrott, Efektywne nauczanie, Warszawa 1995, s. 10.

${ }^{29}$ R. I. Arends, Uczymy się nauczać, Warszawa 1994, s. 36.

${ }^{30}$ L. Cohen, M. Manion, K. Morrison, Wprowadzenie do nauczania, Poznań 1999, s. 30.
} 
Celem badań własnych o charakterze teoretycznym uczyniłam dokonanie diagnozy zasobu kompetencji zawodowych nauczycieli edukacji początkowej na poszczególnych etapach ich profesjonalnego rozwoju oraz ustalenie czynników o tym decydujących. Natomiast celem praktycznym było wskazanie sposobów podtrzymywania profesjonalnej aktywności nauczycieli klas początkowych, efektywności różnych form dokształcania, doskonalenia zawodowego oraz praktycznych sposobów zapobiegania wypaleniu zawodowemu w tej kategorii nauczycieli.

Badania przeprowadziłam w latach 2004/2005 na terenie województwa świętokrzyskiego wśród 529 nauczycieli pierwszego szczebla edukacji oraz dyrektorów pracujących w 101 miejskich i wiejskich szkołach podstawowych. Diagnozie poddałam kompetencje pragmatyczne, komunikacyjno - interpretacyjne, współdziałania, kreatywności oraz informatyczno-medialne ${ }^{31}$. Nauczyciele dokonywali samooceny kompetencji zawodowych, natomiast dyrektorzy oceniali podległych nauczycieli według takich samych kryteriów.

$\mathrm{Z}$ sondażu wynika, że badani nauczyciele wczesnej edukacji opanowali w najwyższym stopniu kompetencje pragmatyczne, komunikacyjno-interpretacyjne oraz kompetencje współdziałania. Reprezentowany przez nich poziom kompetencji kreatywności jest nieco niższy, natomiast najsłabiej wypadli nauczyciele w kategorii kompetencji informatyczno-medialnych (tabela 1).

Tabela 1. Obserwowane wskaźniki ilościowe dotyczące ocen kompetencji nauczycielskich w opinii nauczycieli i dyrektorów w świetle założeń metodologicznych

\begin{tabular}{|c|c|c|c|c|}
\hline \multirow{2}{*}{ Respondenci } & \multirow{2}{*}{ Kategoria kompetencji } & \multicolumn{2}{|c|}{ Zaobserwowane } & \multirow{2}{*}{ Mo } \\
\hline & & $\mathrm{X} \min$ & $\mathrm{X} \max$ & \\
\hline nauczyciele & \multirow{2}{*}{ pragmatyczne } & 13,000 & 39,000 & 39 \\
\hline dyrektorzy & & 13,000 & 39,000 & 39 \\
\hline nauczyciele & \multirow{2}{*}{$\begin{array}{l}\text { interpretacyjno- } \\
\text {-komunikacyjne }\end{array}$} & 7,000 & 21,000 & 21 \\
\hline dyrektorzy & & 8,000 & 21,000 & 21 \\
\hline nauczyciele & \multirow{2}{*}{ współdziałania } & 8,000 & 18,000 & 18 \\
\hline dyrektorzy & & 6,000 & 18,000 & 18 \\
\hline nauczyciele & \multirow{2}{*}{ kreatywności } & 8,000 & 21,000 & 19 \\
\hline dyrektorzy & & 8,000 & 21,000 & 18 \\
\hline nauczyciele & \multirow{2}{*}{ informatyczno-medialne } & 4,000 & 12,000 & 7 \\
\hline dyrektorzy & & 4,000 & 12,000 & 7 \\
\hline
\end{tabular}

$\mathrm{X}$ min - dolna granica rozkładu;

$\mathrm{X} \max$ - górna granica rozkładu;

Mo - moda (wartość najczęstsza, wartość o największym prawdopodobieństwie wystąienia lub wartość najczęściej występująca w próbie).

\footnotetext{
${ }^{31}$ J. Szempruch, Nauczyciel w zmieniającej się szkole - funkcjonowanie i rozwój zawodowy, Rzeszów 2001.
} 
W przeprowadzonych badaniach chodziło ponadto o określenie momentu w karierze zawodowej nauczyciela klas I-III, w którym osiąga on szczyt swojego profesjonalnego rozwoju (tabela 2). Zebrany materiał $\mathrm{z}$ badań pozwolił na stwierdzenie, że według samooceny nauczycieli kompetencje pragmatyczne, komunikacyjno-interpretacyjne, współdziałania i kreatywności są na najwyższym poziomie wśród nauczycieli, których staż pracy mieści się w przedziale między 16 a 25 lat. Są to nauczyciele dyplomowani, w wieku między 41 a 50 lat, określający mistrzostwem swoją fazę rozwoju. Oceny dyrektorów zgodziły się z ocenami nauczycieli w przypadku kompetencji współdziałania i kreatywności, natomiast w przypadku kompetencji pragmatycznych i komunikacyjno-interpretacyjnych przełożeni oceniali wyżej starszych, bardziej doświadczonych zawodowo nauczycieli. Zauważyłam, że oceny dotyczące kompetencji informatyczno-medialnych różnią się znacznie od ocen pozostałych grup kompetencji pedagogicznych. Najlepiej oceniali się młodzi nauczyciele stażyści. Natomiast dyrektorzy oceniali wyżej nauczycieli dłużej pracujących $\mathrm{w}$ zawodzie. W materiałach $\mathrm{z}$ badań odnalazłam również potwierdzenie, iż najwyższy poziom kompetencji posiadają nauczyciele, którzy posiadają dodatkowe kwalifikacje I wciąż je uzupełniają. Na rozwój kwalifikacji zawodowych nauczyciela wczesnej edukacji ma wpływ również jego środowisko zatrudnienia - najwyższe wyniki uzyskali nauczyciele pracujący $\mathrm{w}$ środowisku miejskim. W badaniach przyjęłam, że jednym $\mathrm{z}$ czynników, które hamują rozwój zawodowy nauczyciela jest wypalenie zawodowe. Okazuje się, że problem ten istnieje wśród nauczycieli edukacji wczesnoszkolnej, lecz w niewielkim stopniu.

Tabela 2. Uwarunkowania opinii na temat kompetencji nauczycielskich - porównanie wyników badań nauczycieli i dyrektorów

\begin{tabular}{|c|c|c|c|}
\hline \multirow{2}{*}{$\begin{array}{c}\text { Rodzaje } \\
\text { kompetencji }\end{array}$} & \multirow{2}{*}{ Wybrane zmienne niezależne } & \multicolumn{2}{|c|}{ Kategorie najwyższych ocen } \\
\hline & & nauczyciele & dyrektorzy \\
\hline 1 & 2 & 3 & 4 \\
\hline pragmatyczne & $\begin{array}{l}\text { środowisko zatrudnienia } \\
\text { staż pracy w latach } \\
\text { wiek w latach } \\
\text { stopień awansu } \\
\text { faza rozwoju zawodowego } \\
\text { dodatkowe kwalifikacje }\end{array}$ & $\begin{array}{l}\text { miejskie } \\
16-25 \text { lat } \\
41-50 \text { lat } \\
\text { dyplomowany } \\
\text { mistrzostwo } \\
\text { posiada }\end{array}$ & $\begin{array}{l}\text { miejskie } \\
\text { powyżej } 25 \text { lat } \\
41-50 \text { lat } \\
\text { dyplomowany } \\
\text { mistrzostwo } \\
\text { posiada }\end{array}$ \\
\hline $\begin{array}{l}\text { komunikacyjno } \\
\text { interpretacyjne }\end{array}$ & $\begin{array}{l}\text { środowisko zatrudnienia } \\
\text { staż pracy w latach } \\
\text { wiek w latach } \\
\text { stopień awansu } \\
\text { faza rozwoju zawodowego } \\
\text { dodatkowe kwalifikacje }\end{array}$ & $\begin{array}{l}\text { miejskie } \\
16-25 \text { lat } \\
41-50 \text { lat } \\
\text { dyplomowany } \\
\text { mistrzostwo } \\
\text { posiada }\end{array}$ & $\begin{array}{l}\text { miejskie } \\
\text { powyżej } 25 \text { lat } \\
\text { powyżej } 50 \text { lat } \\
\text { dyplomowany } \\
\text { mistrzostwo } \\
\text { posiada }\end{array}$ \\
\hline
\end{tabular}


Tabela 2 (cd.)

\begin{tabular}{|c|c|c|c|}
\hline 1 & 2 & 3 & 4 \\
\hline współdziałania & $\begin{array}{l}\text { środowisko zatrudnienia } \\
\text { staż pracy w latach } \\
\text { wiek w latach } \\
\text { stopień awansu } \\
\text { faza rozwoju zawodowego } \\
\text { dodatkowe kwalifikacje }\end{array}$ & $\begin{array}{l}\text { miejskie } \\
16-25 \text { lat } \\
41-50 \text { lat } \\
\text { dyplomowany } \\
\text { mistrzostwo } \\
\text { posiada }\end{array}$ & $\begin{array}{l}\text { miejskie } \\
16-25 \text { lat } \\
41-50 \text { lat } \\
\text { dyplomowany } \\
\text { mistrzostwo } \\
\text { posiada }\end{array}$ \\
\hline kreatywności & $\begin{array}{l}\text { środowisko zatrudnienia } \\
\text { staż pracy w latach } \\
\text { wiek w latach } \\
\text { stopień awansu } \\
\text { faza rozwoju zawodowego } \\
\text { dodatkowe kwalifikacje }\end{array}$ & $\begin{array}{l}\text { miejskie } \\
16-25 \text { lat } \\
41-50 \text { lat } \\
\text { dyplomowany } \\
\text { mistrzostwo } \\
\text { posiada } \\
\end{array}$ & $\begin{array}{l}\text { miejskie } \\
16-25 \text { lat } \\
41-50 \text { lat } \\
\text { dyplomowany } \\
\text { mistrzostwo } \\
\text { posiada }\end{array}$ \\
\hline $\begin{array}{l}\text { informatyczno- } \\
\text { medialne }\end{array}$ & $\begin{array}{l}\text { środowisko zatrudnienia } \\
\text { staż pracy w latach } \\
\text { wiek w latach } \\
\text { stopień awansu } \\
\text { faza rozwoju zawodowego } \\
\text { dodatkowe kwalifikacje }\end{array}$ & $\begin{array}{l}\text { miejskie } \\
0-5 \text { lat } \\
\text { do } 30 \text { lat } \\
\text { stażysta } \\
\text { adaptacja } \\
\text { posiada }\end{array}$ & $\begin{array}{l}\text { miejskie } \\
6-15 \text { lat } \\
41-50 \text { lat } \\
\text { dyplomowany } \\
\text { mistrzostwo } \\
\text { posiada }\end{array}$ \\
\hline
\end{tabular}

Dokonane $\mathrm{w}$ toku przeprowadzonych badań spostrzeżenia dały ciekawy, nowy materiał oświetlający rzeczywistość edukacyjną i pozwoliły na odkrycie nowych problemów wymagających dalszych badań. Upoważniają również do sformułowania kilku ogólnych wniosków dla teorii i praktyki pedagogicznej.

Mianowicie, badania dowiodły, że poziom kompetencji pragmatycznych wśród nauczycieli klas początkowych jest wysoki. Jednak w zakresie opanowania wiedzy z edukacji muzycznej oraz plastyczno-technicznej nauczyciele nie oceniają się najlepiej. Gdzie leży przyczyna takiego stanu rzeczy? Czy powodem jest słabe przygotowanie zawodowe do realizacji tych edukacji, czy stopień złożoności niektórych wiadomości i umiejętności muzycznych i plastycznotechnicznych przekracza możliwości nauczycieli bez kierunkowego wykształcenia muzycznego czy plastycznego, czy też nauczyciele nie posiadają wrodzonych zdolności plastycznych, talentu muzycznego? Istotną kwestią jest rozstrzygnięcie tego problemu już na etapie rekrutowania przyszłych nauczycieli na kierunki pedagogiczne, gdzie sprawdzian praktycznych umiejętności powinien wyeliminować osoby, które nie są wyposażone w umiejętności konieczne dla efektywnej pracy nauczyciela w klasach I-III. Zasadne jest, aby podczas kształcenia kandydatów na nauczycieli więcej czasu przeznaczać na rozwijanie umiejętności plastycznych, technicznych oraz muzycznych.

Badania pozwalają na stwierdzenie, że kompetencje interpretacyjno-komunikacyjne są wysoko rozwinięte u badanych nauczycieli. Pomimo tego dostrzegłam pewne nieprawidłowości w procesie komunikacji nauczyciel - uczeń. Niekiedy jest to brak kontroli nad emocjami w kontaktach z uczniami oraz nie zezwalanie im na samodzielne wypowiadanie się oraz zbyt słabe przywiązywanie 
uwagi do wypowiedzi ucznia. Dlatego pomocne nauczycielom wczesnej edukacji może stać się zwrócenie baczniejszej uwagi na panowanie nad własnymi zachowaniami oraz rozwijanie umiejętności wsłuchiwania się w to, co mówi do nich dziecko, ponieważ w procesie komunikacji istotną stroną jest nie tylko przekaz, ale również odbiór. Uczestnictwo w różnych formach doskonalenia zawodowego z zakresu komunikacji interpersonalnej również może przyczynić się do wzbogacania kompetencji interpretacyjno-komunikacyjnych.

Wypowiedzi badanych osób pozwalają zaobserwować, że ocena poziomu kompetencji współdziałania u nauczycieli jest wysoka. Jednakże, zgłębiając wyniki badań w tej kategorii, zauważyłam, iż nauczyciele nie doceniają możliwości korzystania z pomocy instytucji wspierających pracę szkoły, np. poradni psychologiczno-pedagogicznej. Ważne jest uświadomienie nauczycielom profitów wynikających ze współpracy z poradnią. Pracownicy poradni psychologiczno-pedagogicznej organizują szkolenia i warsztaty dla nauczycieli, konsultacje na terenie poradni i szkół z zakresu, np. sposobów oceny postępów rozwojowych dziecka oraz wspomagania jego rozwoju, zapewniają specjalistyczną pomoc dla dzieci o różnych potrzebach edukacyjnych, oferują pomoc w tworzeniu programów zajęć korekcyjno-kompensacyjnych.

Stan kompetencji kreatywności nie jest już tak zadowalający, jak w przypadku pozostałych grup kompetencji nauczycieli klas początkowych. Największą trudność sprawia nauczycielom pisanie własnych projektów edukacyjnych, głównie programów autorskich, ale też scenariuszy. W toku kształcenia nauczycieli na studiach wyższych powinno się zwrócić szczególną uwagę na wyposażenie nauczycieli w umiejętności konstruowania programów, wprowadzania do nich nowych koncepcji, celów i treści zgodnych z podstawą programową i stanowiących jej uzupełnienie, ponieważ „bycie twórczym” to kluczowa kompetencja współczesnego nauczyciela wczesnej edukacji. Tym bardziej, że pojawiły się wreszcie publikacje przybliżające tę problematykę, np. Irena Adamek, Teoretyczne i praktyczne podstawy konstruowania programów szkolnych ${ }^{32}$.

Skoro stan kompetencji informatyczno-medialnych okazał się niski, istnieje potrzeba uświadomienia nauczycielom znaczenia umiejętności posługiwania się technologią informacyjną dla funkcjonowania we współczesnym świecie. Kształcenie tego rodzaju kompetencji na etapie studiów wyższych jest fundamentem przygotowania do pracy pedagogicznej. Należy unaocznić nauczycielom edukacji wczesnoszkolnej, że środki multimedialne są szansą na rozwój dziecka, wzbogacanie procesu edukacyjnego, a także na rozwój kariery zawodowej. Nieodzowne staje się profesjonalne przygotowywanie nauczycieli w zakresie wykorzystania komputera na etapie nauczania początkowego. Jednym ze sposobów może być przeprowadzenie kursów informatycznych, których celem będzie zaznajamianie ich $\mathrm{z}$ dostępnym na rynku oprogramowaniem edukacyjnym do zastosowania w klasach I-III.

${ }^{32}$ I. Adamek, Teoretyczne i praktyczne podstawy konstruowania programów szkolnych, Kraków 2007. 
Przeprowadzone badania pozwalają na stwierdzenie, że poziom kompetencji zawodowych nauczycieli klas początkowych jest zróżnicowany środowiskowo na niekorzyść środowiska wiejskiego. Istotne jest zwrócenie uwagi na poprawę warunków w miejscu pracy oraz na możliwość zdobycia przez władze szkolne licznych dofinansowań, dzięki którym stanie się możliwe, np. wzbogacenie bazy materialnej szkoły w postaci nowych pomocy dydaktycznych, nowych książek do biblioteki szkolnej, sprzętu sportowego czy stworzenie szkolnej pracowni informatycznej z dostępem do Internetu. Współpraca z różnymi instytucjami, organizacjami, tj. domami kultury, bibliotekami, stowarzyszeniami lokalnymi może okazać się pomocna przy rozwijaniu kompetencji nauczycielskich poprzez realizację dodatkowych zajęć i projektów edukacyjnych czy też udostępnianie swojej infrastruktury.

Badania wykazały, że problem wypalenia zawodowego istnieje wśród badanych nauczycieli w niewielkim stopniu. Dlatego w przygotowywaniu nauczycieli do zawodu w czasie studiów zasadne może być uwzględnienie profilaktyki wypalenia, sposobów radzenia sobie ze stresem. Warto pamiętać, że sama świadomość istnienia wypalenia jest istotnym czynnikiem w przeciwdziałaniu jego powstawania.

Poruszane w pracy problemy mogą budzić wiele pytań. W tej sytuacji istotne wydaje się ciagłe poszukiwanie najlepszych rozwiązań w zakresie rozwijania kompetencji zawodowych nauczycieli wczesnej edukacji.

ANNA SZKOLAK

\section{The pedagogical competences of early childhood education teachers - an account of the research}

In my article I deal with the problems connected with the debate on the Polish teacher condition in the situation of the system transformation, changes in the Polish school and new challenges which it faces. The particular role in this process, I ascribe an early childhood education teacher and I pose the questions on how this teacher is equipped as far as his or her pedagogical competences are concerned. I also take into consideration the subject matter of the teacher professional development and also internal factors (personality, burnout syndrome) and external factors (professional advancement, didactic staff mutual relations, school localization), which are in respect to these competences. Formulated problems and assumed hypotheses have become the starting point for empirical research carried out in the properly selected environments (town and rural). A group of 529 teachers took part in this research whose professionalism was valued on the basis of self-assessment and observation results made by 101 headmasters. The obtained empirical documentation is the base for quantitative and qualitative analysis of indexes determining the level of selected ,pedagogical competences" and factors conditioning these competences. The research results gave the empirical material proving the fact that early childhood education teachers present a good level of professional pragmatic competences, communicative-interpretative and cooperation competences, on the other hand, their creativity competences and computer science and media competences turned out to be worse. This diversity creates important circumstances which induce to carry out further research. 